\title{
Bilgi Okuryazarlığı Becerilerinin Geliştirilmesinde Kütüphanelerin Rolü ve Dokuz Eylül Üniversitesi Uygulaması
}

\author{
The Role of Libraries in the Development Information \\ Literacy Skills and Application of Dokuz Eylul University
}

\section{Ömür Saatçioğlu*, Ömür Özmen** ve Pınar Sürel Özer ${ }^{\star \star \star}$}

\begin{abstract}
Öz
Günümüzdeki hızlı değişim ve gelişimin etkilerinin en çok hissedildiği alanlardan biri üniversite eğitimi ve kütüphanelerdir. Teknolojik gelişmeler üniversite eğitimi ve kütüphanelerinin yeniden yapılanmasını kaçınılmaz kılan önemli faktörlerden biridir. Yeniden yapılanma sürecinde üniversite eğitimi sırasında kazanılması gereken beceriler önem kazanmaktadır. Bunlardan biri yaşamboyu öğrenmeye ve öğrenmeyi öğrenmeye önemli katkılar sağlayan bilgi okuryazarlığıdır. Bilgi okuryazarlığı uygulamalarının geliştirilmesinde kütüphane ve kütüphanecilerin rolü gittikçe artmaktadır. Bu çalışmanın amacı, bilgi okuryazarlığının gelişimi ile üniversite eğitimi ve kütüphanelerde yarattığı değişimi tanımlamak; Dokuz Eylül Üniversitesinde geliştirilecek bilgi okuryazarlığı uygulamaları kapsamında kütüphane ve kütüphanecilerinin konumunu belirlemektir.
\end{abstract}

Anahtar sözcükler: Bilgi okuryazarlığı, Bilgi okuryazarlığı eğitimi, Üniversite kütüphaneleri.

* Dr.; Dokuz Eylül Üniversitesi Iktisadi ve Idari Bilimler Fakültesi 35160 Buca-IZMiR (ysaatci@deu.edu.tr)

** Prof.Dr.; Dokuz Eylül Üniversitesi Işletme Fakültesi Yönetim Organizasyon ABD, Kaynaklar Yerleşkesi 35160 Buca - Izmir (omur.ozmen@deu.edu.tr).

**Dr.; Dokuz Eylül Üniversitesi Iktisadi ve Idari Bilimler Fakültesi 35160 Buca-Izmir (pinar.ozer@deu.edu.tr). 


\begin{abstract}
One of the areas where the impact of rapid change and developments most is the university education and libraries. Especially, technological development is one of the most important factors that affect the restructuring of university education and libraries is unavoidable. The skills that should be obtained throughout the university education carry the outmost importance in the restructuring process. One of these skills, which will make the major contribution to lifelong learning and learning how to learn, is information literacy. The role of library and librarians are increasing in the development of information literacy applications. The objective of this article is to define the development of information literacy; the changes in university education and libraries resulting from development of information literacy and to determine the position of library and librarians in the information literacy applications of Dokuz Eylul University.
\end{abstract}

Keywords: Information literacy, Information literacy education, University libraries.

\title{
Giriş
}

Üniversitelerin insanlık tarihinde eski bir geçmişi olmasına karşın, çağdaş anlamda üniversite anlayışı, başka bir anlatımla eğitim ve öğretimin yanında araştırmaya da önem verilmesi 19.yüzyılın başlarında Berlin Üniversitesinin kurulması ile başlamıştır. O zamana kadar üniversite içinde öğretim üyelerinin ve öğrencilerin yararlandığı bir kütüphane hizmeti olmasına rağmen, gerçek bir üniversite kütüphanesinin ortaya çıkması, araştırma etkinliklerinin üniversitenin temel işlevlerinden biri olduğu ilkesinin benimsenmesi sonucudur. "Araştırma ile Öğretimin Birliğï" ilkesi, başta Amerika Birleşik Devletleri (ABD) olmak üzere birçok ülkedeki üniversite gelişimini etkilemiştir. ABD'deki üniversite sisteminin önemli isimlerinden Whitehead'e göre "üniversite bir ilerleme ve gelişme merkezi olup, ilerleme ve gelişme eğitim-öğretimle araştırmanın karşılıklı etkileşimiyle sağlanabilir” (Çakın, 1998, s. 37). Bu gelişmeden hareketle, 19.yüzyıldan itibaren Batı'da üniversitelerin ve kütüphanelerin hızIı bir gelişme gösterdiği söylenebilir. Lucker, 20.yüzyıldan itibaren üniversite 
kütüphanesinin "üniversitenin kalbi” haline geldiğini ve aşağıdaki gelişmelerin görüldüğünü belirtmektedir (Çelik, 2000, s. 47):

-Kapalı raf sistemlerinden açık raf sistemlerine geçilmiştir,

-Bireysel okuma alanlarına ağırlık verilmiştir,

-Okuyucu hizmetlerinin bulunduğu alanda kullanıcılarla, kütüphane personelinin etkileşimi ön plana çıkmıştır,

-Kütüphanenin, üniversitenin eğitim ve öğretim etkinliklerinde payı artmıştır.

Üniversite kütüphanelerinin gelişmesinde diğer bir dönüm noktası da, Íkinci Dünya Savaşı sırasında araştırmaya büyük mali kaynaklar ayrıması, pek çok bilimsel gelişme sağlanması ve savaşın bitiminde de bu bilgilerin yayınlanmaya başlaması ile bir yayın patlamasının ortaya çıkmasıdır.

\section{Bilgi Döngüsü, Üniversiteler ve Kütüphaneler}

Günümüzde bilgi, kitap ve süreli yayın gibi basılı kaynakların yanı sıra, video kaset, ses kaseti, mikrofilm, CD-ROM ve internet gibi farklı ortamlarda da saklanabilmektedir. Bilginin bu şekilde farklı ortamlarda yayılmasında ise, kütüphanelerin önemi göz ardı edilmemelidir. Kütüphanelerin bilgi altyapısındaki rolünün irdelenmesinde Tablo 1'in incelenmesi faydalı olacaktır.

\begin{tabular}{|l|c|c|c|c|}
\hline $\begin{array}{c}\text { Bilgi } \\
\text { Üreticileri }\end{array}$ & $\begin{array}{c}\text { Bilgi } \\
\text { Ürünleri }\end{array}$ & $\begin{array}{c}\text { Bilgi } \\
\text { Dağıtıcıları }\end{array}$ & $\begin{array}{c}\text { Bilgi Paylaşma } \\
\text { Ortamları }\end{array}$ & $\begin{array}{c}\text { Bilgi } \\
\text { Kullanıcıları }\end{array}$ \\
\hline Yazarlar & Kitaplar & Yayın evleri & Okullar & Bireyler \\
\hline $\begin{array}{l}\text { Sanatçılar } \\
\text { Veritabanı } \\
\text { üreticileri }\end{array}$ & CD-ROM & $\begin{array}{c}\text { Internet servis } \\
\text { sağlayıcılar }\end{array}$ & Uütüphaneler & Araştırmacrısiar \\
\hline Kurumlar & Veri tabanları & & Öğrenciler \\
\hline & Web sayfaları & & Müzeler & Işverenler \\
\hline & & & Işletmeler & Çalışanlar \\
\hline
\end{tabular}

Tablo 1: Bilgi Döngüsünün Bir Parçası Olarak Bilgi Altyapısı ve Bileşenleri Kaynak: Rubin (1998, s. 3). 
Tablo 1'de görüldüğü gibi, farklı kişi ve kurumlar tarafından üretilen bilginin, farklı gereksinimlere sahip kullanıcılara iletilmesinde rol oynayan en önemli ortamlardan ikisi üniversiteler ve kütüphanelerdir. Üniversiteler gerçekleştirdikleri eğitim ve araştırma faaliyetleriyle; ülkelerin ekonomik gelişmelerine katkı sağlamaktadır. Dolayısıyla; üniversitelerin eğitim ve araştırma kalitelerinin artması ülkelerin gelişmelerine önemli bir ivme kazandırmaktadır. Üniversite ve ülkenin gelişmişlik düzeyi arasındaki ilişkinin belirlenmesinin ardından cevaplanması gereken soru, üniversitelerin gelişimine katkıda bulunan öncelikli faktörlerin neler olduğudur. Bu faktörlerden birinin, üniversitenin temel işlevlerinden olan eğitim ve araştırmaya sağladıkları destek nedeniyle kütüphaneler olduğu söylenebilir. Üniversite ve kütüphane arasındaki ilişkinin önemi, Çakın (2000, s. 29) tarafından "uluslararası düzeyde tanınmış hiç bir üniversite yoktur ki kütüphaneleri gelişmemiş, tanınmayan hiç bir üniversite yoktur ki kütüphaneleri gelişmiş olsun" şeklinde ifade edilmiştir.

Kütüphane ve üniversite eğitimi arasındaki ilişkinin gücü ve önemi, kütüphaneleri "üniversitenin kalbi" haline getirirken; üniversitelerin temel işlevlerinden olduğu kabul edilen eğitim, öğretim ve araştırmanın kütüphane ile bütünleşmesini kaçınılmaz kılmaktadır. İlk defa 1958'de Detroit Wayne Üniversitesinde Knapp, kütüphanenin üniversite içinde daha etkin bir konumda olabilmesi için ders programlarının belirlenmesinde öğretim üyeleriyle birlikte kütüphanecilerin de rol almasını önermiştir (Rader, 1995, s. 270). Bununla birlikte, yükseköğrenimin karşı karşıya kaldığı değişimde kütüphanelerin rolü ilk defa 1986 yılında yayınlanan Carnegie Raporu'nda vurgulanmıştır. “College: The Undergraduate Experience in America" başlıklı raporun, Ernest L.Boyer tarafından yazılan "Resources: Printed Page and Printouts" bölümünde kütüphanecilerin konumu tartışılmaktadır. Raporun öneriler bölümünde şu ifadeler yer almaktadır (ALA, 1989):

"Bir üniversitenin kalitesi, kampüsteki bilgi kaynakları ve öğrencilerin bağımsız, kendini öğrenmeye yönlendiren bireyler olmalarıyla ölçülür. Günümüzde, bir hafta içinde her dört öğrenciden biri kütüphaneye hiç gitmemekte; öğrencilerin \%65’i kütüphaneyi haftada dört saat veya daha az kullanmaktadır. Yarım yüzyıl önce belirtilen sınıf ve kütüphane arasındaki uzaklık hala varlığını korumaktadır". 
Üniversite ve kütüphane arasındaki bu uzaklığın sürmesi nedeniyle öğrenciler, bilgi kaynaklarının özellikleri ve kullanımına yönelik yeterli bilgi sahibi olmadan mezun olmaktadırlar. Günümüzde bilimsel alanda ülkelerin rekabet açısından üstünlük sağlayabilmeleri için sahip olduğu bilgilerini yönetebilen; bir başka ifadeyle bilgi gereksinimini bilen, bilgiye erişebilen, kullanabilen ve onu değerlendirebilen bireylere gereksinim vardır. Bu özellikleri taşıyanlar bilgi okuryazarlığı becerilerine sahip olan kişilerdir.

\section{Bilgi Okuryazarlığı Becerileri}

Bilgi teknolojilerinin hızlı gelişimi sonucunda, sanayi toplumundan bilgi toplumuna geçiş aşamasında tüm bireylerin yaşamlarını kolaylaştıracak ve zenginleştirecek bilgiye erişim olanağı artmaktadır. Bilgi erişiminin gerekliliği Alvin Toffler (1992) tarafından "geleceğin cahili okuma yazma bilmeyen değil de, bilgiye nasıl erişileceğini bilmeyendir" şeklinde ifade edilmektedir (Aktaran: Tonta, 2002, s. 54). Bireylerin kendileriyle ve işleriyle ilgili gereksinim duydukları bilgiye erişebilmesinin kolaylaşmasının yanında elde edilebilecek bilgi miktarının artması aşırı bilgi yükü (information overload) problemini de beraberinde getirmiştir. Bilgi yükünün karar verme yeteneklerini \%50 azalttığı bilinmektedir (Sprague ve Watson, 1996, s. 185). Bilgi miktarındaki artış bilgiye ulaşma becerilerinin gelişmesini gerektirirken, sürekli yeni bilgi üretimi yaşam boyu öğrenmeyi zorunlu kılmaktadır. Elektronik ortamlardaki bilginin artması, öğretim, eğitim ve araştırmalarda etkin olarak kullanılmasının artması ve yaşam boyu öğrenmenin gerekliliği, bilgi okuryazarlığı becerilerinin yüksek öğretimde kazanılmasını zorunlu hale getirmektedir.

Bilgi okuryazarlığı terimi, ilk olarak 1974 yılında Paul Zurkowski tarafından yazılan bir raporda "işleriyle ilgili bilgi kaynaklarını kullanabilmek üzere bireylerin eğitilmesi" şeklinde ifade edilmiştir. Bilgi okuryazarını, "birçok bilgi kaynağını kullanma becerisi yanında problemlere bilgiye dayalı çözümler oluşturmak için temel kaynaklara ulaşabilme becerisine de sahip bireyler" olarak nitelendirilmiştir. Zurkowski, raporda 1984 yılına kadar bilgi okuryazarlığı becerilerinin geliştirilmesine yönelik ulusal bir program oluşturulmasını da önermiştir (Doyle, 1994, s. 5). Bilgi okuryazarlığı tanımı ilk olarak Kütüphaneler ve Ulusal Bilgi Bilimi Komisyonuna (National Commission on Library and 
Information Science) sunulan ve ABD için bir ulusal program geliştirilmesini öneren bu raporda yer almıştır. Bilgi okuryazarlığı için, daha sonra birçok tanım yapılmasına rağmen, genellikle Amerikan Kütüphane Derneği (American Library Association-ALA) tarafından geliştirilen tanım kaynak gösterilmektedir. Bu tanıma göre; "bilgi okuryazarı olanlar öğrenmeyi öğrenmiş bireylerdir. Öğrenmeyi öğrenmiş olmalarının nedeni, bilginin nasıl düzenlendiğini, bilgiye nasıl ulaşılacağını bilmeleri ve diğer bireylerin öğrenebileceği şekilde bilgiyi düzenleyebilmeleridir. Bilgi okuryazarı bireylerin yaşam boyu öğrenmeye hazır olmalarının nedeni, herhangi bir iş veya karara yönelik bilgilere kolayca erişebilmeleridir" (ALA, 1989).

ALA'nın tanımından sonra, bilgi okuryazarlığı hızla gelişen ve gelişmesini sürdürecek bir alan olarak karşımıza çıkmaktadır. Bilgi okuryazarlığı becerilerini kazandırmayı hedefleyen bilgi okuryazarlığı eğitimi, Amerikan Üniversite ve Araştırma Kütüphaneleri (American College and Research Libraries ACRL) (2000) tarafından saptanan standartlar temel alınarak geliştirilmelidir. Bu standartlar; bilgi gereksiniminin belirlenmesi, bilgiye etkin biçimde erişimin sağlanması, bilgi ve bilgi kaynaklarının değerlendirilmesi; bilginin bir amaca ulaşmak için bireysel veya grup çalışmalarında aktif biçimde etik kurallara uygun ve yasal olarak kullanılması ile ilgilidir.

\section{Bilgi Okuryazarlığı Eğitimi ve Uygulamalarda İşbirliği}

Bilgi okuryazarlığı eğitimi kullanıcı eğitimi, kütüphane tanıtımı ve bibliyografik öğretimin bir uzantısı olarak incelenmelidir. Bununla birlikte, bilgi okuryazarlığı eğitiminin farkı belirlenmelidir. Günümüzde geçmişten farklı olarak bilginin her yerde olması kullanıcıların bilgi kalitesini değerlendirmesinde sorunlar yaşamasına neden olmakta ve bilgiyi eleştiren, sorgulayan kullanıcılara duyulan gereksinimi artırmaktadır. Veri tabanlarının, arama motorlarının, basılı ve basılı olmayan bilgi kaynaklarının kullanımı, bilgi okuryazarı bir bireyin sahip olması gereken becerilerdir. Bunlara ek olarak; herhangi bir kaynağın diğer bir kaynakla karşılaştırıldığında tercih edilme nedeni, seçilen kaynağın sorgulanarak değerlendirilmesi ve araştırılan konuya uygun olan kaynakların belirlenmesi bilgi okuryazarlığının önemli bileşenlerindendir (Grassian ve Kaplowitz, 2001, s. 9). Böylece; bilgi okuryazarlığı becerilerine sahip olan 
öğrenciler bağımsız araştırmacılar olarak öğrenmeyi öğrenmektedirler (Angeley ve Purdue, 2000). Kütüphaneciler, araştırma sürecinde bilginin değerlendirilmesinde bireylere yardım etmektedir. Internet kaynaklarına bağımlılığın artması, bilginin ve bilgi kaynaklarının değerlendirilmesinde kütüphanecilerin uzmanlığının ve objektifliğinin değerini artırmaktadır (ACRL, 2001). Bu nedenle; kütüphaneciler kendilerini bilgi çağında aktif katılımcı uzmanlar olarak görmektedirler (Doherty, Hansen ve Kaya, 1999).

Bilgi okuryazarlığı uygulamalarının başarısını etkileyen faktörlerle ilgili olarak Bilgi Okuryazarlığı Enstitüsü (National Information Literacy Institute) tarafından yapılan bir araştırmada başarı faktörleri "Ders Programıyla Bütünleşme", "Öğretim Üyeleriyle İşbirliği" ve "Pedagoji" olmak üzere üç başlık altında toplanmıştır (Oberman, 2002, s. 3). Bilgi Okuryazarlığı Enstitüsü, ALA tarafından 1997'de kurulmuştur. Bilgi Okuryazarlığı Enstitüsü'nün amaçları; kütüphanecileri bilgi okuryazarlığı uygulamalarının etkin öğretmenleri olarak hazırlamak; kütüphaneciler, diğer eğitimciler ve yöneticileri bilgi okuryazarlığı programlarının geliştirilmesinde ve uygulanmasında lider olarak desteklemek; eğitimciler arasında bilgi okuryazarlığı müfredatı geliştirilmesine yönelik yeni düzenlemeler geliştirmek ve bilgi okuryazarlığının gelişiminde fırsatlar sunmak olarak açıklanmaktadır (ACRL, 2002).

Bilgi okuryazarlığı uygulamalarının geliştirilmesi amacıyla, oluşturulacak işbirliğinde tarafların kimler olacağı kurumlara göre farklılık gösterebilir. Bazı araştırmalarda öğretim üyeleri, kütüphaneciler, bilgi teknolojisi uzmanları ve öğrencilerin beraber çalışması (Rader, 1998); bazı araştırmalarda yöneticiler de dahil olmak üzere eğitimle ilgili herkesin bulunması (Miller ve Anderson, 1996, s. 13); bazılarında ise yöneticiler, öğretim üyeleri ve kütüphanecilerin (Oberman, 2002, s. 1; ACRL, 2002) işbirliği içinde çalışmaları önerilmektedir. Kütüphaneciler, işbirliğinin oluşturulması dışında eğitimde de önemli rol oynamaktadır (Meulemans ve Brown, 2001, s. 254). ALA (1998) raporunda, bilgi okuryazarlığı eğitim programlarının geliştirilmesinde kütüphane dernekleriyle de işbirliği yapılmasının gerekliliği vurgulanmaktadır. 


\section{Bilgi Okuryazarlığı Eğitiminde Kütüphanecilerin Rolü ve Görevi}

Bilgi okuryazarlığı eğitimi uygulamalarında yer alacak taraflar kurumlara göre değişebilir. Bununla birlikte; ortak olan özellik, her işbirliğinde kütüphanecilerin mutlaka yer alması ancak görevlerinin farklılık göstermesidir. Bu bağlamda, kütüphanecilerin görevleri aşağıdaki şekilde sıralanabilir (Rader, 1998; ACRL, 1997; Kurbanoğlu, 2001, s. 16; Oberman, 2002, s. 1):

- Değişen teknoloji, çevre ve topluluklara uyum göstermek,

- Eğitim, öğretim alanındaki gelişmeleri takip etmek, ders programlarının geliştirilmesinde rol almak,

- Bilgi bilimi alanındaki çalışmaları izlemek, elektronik bilgiyi ders programlarıyla bütünleştirmek, bilgi teknolojilerini eğitimde kullanmak isteyen öğretim üyelerine yardımcı olmak,

- Öğrencilerin bilgi becerilerini geliştirmelerine ve öğrenmelerine yardımcı olmak, okumaya ilgisini artıracak çalışmalar yapmak,

- Bireylere veya gruplara göre farklı eğitim programları tasarlamak, bunları güncellemek ve yorumlamak ve ilgili komitelerde yer almak,

- Yaşam boyu öğrenmeyi destekleyecek bir koleksiyon oluşturmak amacıyla kullanıcı gereksinimlerini izlemek,

- Her formattaki bilgiye erişim sağlamak,

- Diğer kütüphaneler ve bilgi merkezleriyle işbirliği yaparak kütüphane koleksiyonu dışından bilgi sağlama işlemlerini gerçekleştirmek,

- Öğretim üyeleriyle kütüphane dışında iletişim kurmaktır.

Kütüphanecilerin tanımlanan görevleri gerçekleştirebilmeleri ve eğitimde etkin rol alabilmeleri için bazı koşulların gerçekleşmesi gerekmektedir. Bu koşullar şöyle açıklanmaktadır (ACRL, 2002):

- Kütüphane ve kurum yönetiminden destek almak,

- Eğitimde uzman bir kütüphanecinin kurumsal değişim için öğretim üyeleriyle beraber çalışması,

- Öğretim üyelerinin kütüphaneciler ve diğer uzmanlarla beraber işbirliğinin geliştirilmesinde öncü rol alması. 
Literatürden anlaşıldığı gibi, kütüphanecilerin bilgi okuryazarlığı uygulamalarına katkıları farklı biçimde ve düzeyde olabilmektedir. Bunlar; "danışma kütüphaneciliği, araştırmalarda danışmanlık, bireyselleştirilmiş eğitim, elektronik veya yazılı yardımlar, geleneksel veya laboratuvarlarda eğitim" ve benzerleri olarak sıralanabilir (ACRL, 1997). Ancak, kimlerin bilgi okuryazarlığı eğitimine katılacağı, kıt kaynakların en etkin nasıl kullanılabileceği, tüm kütüphanecilerin mi yoksa bunlardan bazılarının mı eğitim sürecine dahil olacağı, bilgi okuryazarlığı eğitimi verecek kütüphaneciler açısından hangi becerilerin gerektiği ve nasıl geliştirileceği, uygulanacak eğitim yöntemlerini çalışanlar açısından olumlu ya da olumsuz yönleri gibi cevaplanması gereken sorular da bulunmaktadır (McCool, 1989, s. 18).

Kütüphanecilerin, bir taraftan bilgi okuryazarı toplum ve/veya bilgi toplumu yaratma sorumluluğu ile bireyleri bilinçlendirmek ve bilgilendirmek için çaba gösterirken, diğer taraftan yeni bilgi ve uzmanlık alanlarına yönelmeleri, değişimin getirilerine hazır olmaları, değişen gereksinimlere yanıt vermek üzere sürekli eğitim programları ile desteklenmeleri, hepsinden önemlisi yaşam boyu öğrenme anlayışına sahip olmaları gerekmektedir (Gürdal, 2000, s. 185-186). Belirtilen şartların yanında, kütüphanecilerin yaratıcı ve kendi uzmanlık alanlarında her tür bilgi ile donatılmış olmaları ve bunları aktarmaya istekli olmaları gereklidir (Çapar ve Gürdal, 2001, s. 409).

\section{Araştırmanın Amacı}

Yukarıda sözü edilen gelişmelerden hareketle Dokuz Eylül Üniversitesi (DEÜ) yönetimi 2002-2003 akademik yılında başlamak üzere bilgi okuryazarlığı projesi uygulanmasına karar vermiştir. Bu projenin ana amacı, üniversite kütüphane ve kütüphanecilerinin bu alandaki rolünü etkin hale getirerek öğretim üyeleriyle işbirliği yapmak, böylece bilgi okuryazarı mezunlar yetiştirmek üzere programlar geliştirmektir.

Burada sunulan bilgiler, araştırma projesinin ilk aşamasını oluşturmakta bilgi okuryazarlığı becerilerinin kazandırımasında DEÜ Kütüphaneleri ve kütüphanecilerinin konumunu belirlemeyi amaçlamaktadır. Bu kapsam çerçevesinde üniversite kütüphanesinin misyonunu oluşturmak, durum analizi yaparak kütüphanelerin güçlü ve zayıf yönlerini, çevresel tehdit ve fırsatları saptamak, kütüphanecilerin bilgi okuryazarlığının geliştirilmesindeki rollerini algılamalarını değerlendirmek hedeflenmiştir. 


\section{Araştırmanın Kapsamı}

Araştırmanın kapsamını Dokuz Eylül Üniversitesi Kütüphaneleri ve kütüphanecileri oluşturmaktadır. Merkez Kütüphane yanında fakülte, yüksekokul ve enstitülerde açılmış olan birim kütüphaneleriyle birlikte DEÜ'de toplam 15 kütüphane bulunmaktadır. Temmuz 2003 itibariyle tüm kütüphanelerindeki toplam kitap sayısı 275.859' dur. Yabancı dillerde 726, Türkçe 358 olmak üzere devam eden süreli yayın sayısının toplamı 1084'dür. Elektronik bilgi erişim sistemlerindeki gelişmelerden, yararlanabilmek için kütüphaneler internete bağlanmış, çeşitli konularda 20 çevrim içi ve 8 CD-ROM veri tabanına abone olunmuştur. Toplam 24 kütüphane personelinden 15'i kütüphanecilik eğitimi almıştır.

DEÜ Kütüphaneleri, üniversite dışındaki araştırmacılara da bilgi hizmeti sunmaktadır.

\section{Araştırma Planı}

Bu çalışma, bilgi okuryazarlığı konusunda yayın ve uygulamaların incelendiği bir literatür taraması ile başlamıştır. Öncelikle, bilgi okuryazarı̆̆ının tanımları, aşamaları, beceri kazandırılmasına ilişkin olarak geliştirilen yöntemler, eğitim programları, yapılan uygulamalar, öğretim elemanları ve kütüphanecilerin rolleri ile ilgili kaynaklar taranmıştır. Bilgi okuryazarlığı uygulamaları incelenerek DEÜ'de geliştirilecek bilgi okuryazarlığı ugulamalarının temeli oluşturulmuştur.

Daha sonra uygulamanın ne şekilde yürütüleceğine ilişkin bir program geliştirilmiştir. Illk olarak bilgi okuryazarlığı konusu üniversite içinde toplantılar ve bilgilendirme yazıları ile tanıtılmaya ve alınan geri bildirimlerle programın etkinliğinin arttırımasına çalışımıştır. İkinci olarak DEÜ Kütüphaneleri ve kütüphanecilerinin bu projedeki konumlarının belirlenmesine geçilmiştir.

\section{Yöntem ve Veri Toplama Araçları}

Bu çalışmada, belirlenen amaca ulaşabilmek için betimleme yöntemi kullanılmıştır. Uygulanan projede, küçük grup çalışmaları yapılmış, veri toplamak için de anket çalışması tercih edilmiştir. Kütüphanenin misyonunun belirlen- 
mesi için kullanılan yöntemler ise içerik analizi tekniklerinden kategorisel analiz ve SWOT (durum) analizi olarak açıklanabilir.

Içerik analizinde, kategorisel analiz tekniği kullanılmıştır. Bu teknik, belirli bir mesajın önce birimlere bölünmesini, ardından bu birimlerin, belirli kriterlere göre gruplandırılmasını ifade eder. Kategorilerin belirlenmesinde uyulacak bazı teknik esaslar vardır. Kategorilerin homojen, ayırt edici, objektif olması, bütünsellik taşıması, amaca uygun ve anlamlı olması gerekir (Bilgin, 2000, s. 15). Durum analizi ise, bir kurum ya da kuruluşun stratejik kararlar alabilmesine yardımcı olmak üzere güçlü ve zayıf yanlarının, çevredeki fırsat ve tehditlerin değerlendirilmesidir (Darft, 1991, s. 156).

\section{Uygulama}

Projenin, DEÜ Kütüphaneleri ve kütüphanecilerinin konumunun belirlenmesi aşamasını gerçekleştirebilmek üzere üniversite yönetimi tarafından bir toplantı yapılmış ve katıım zorunlu tutulmuştur. Ancak, bir kısım çalışan sağlık sorunları ve çeşitli görevler nedeniyle toplantıya katılamaz iken; 24 kütüphaneci ve 16 kütüphane görevlisi toplantıya katılmıştır (\%66). Toplantıda ilk olarak, bilgi okuryazarlığı uygulamaları proje yürütücüleri tarafından tanıtıımıştır. Daha sonra bilgi okuryazarlığı uygulamalarının geliştirilmesinde çalışanların ortak bir amaç doğrultusunda birleştirilmesinde önemli bir yeri olan misyon kavramı üzerinde durulmuştur. Yurt içi ve yurt dışından çeşitli üniversitelerin ana misyonları ile kütüphane misyonlarından örnekler verilmiş ve aralarındaki ilişkiler bilgi okuryazarlığı uygulamaları kapsamında tartışımıştır. Projede yer alan bilgi teknolojileri, öğrenmeyi öğrenme ve bilgi kaynaklarının kullanımı ile ilgili kavramlara dikkat çekilmiş̧ir. Bunun ardından dörder kişilik gruplar oluşturulmuş ve üniversite için bir kütüphane misyonu geliştirilmesine yönelik çalışmalar yapılmıştır. Kişilerden öncelikle kendi önerilerini geliştirmeleri istenmiştir. Daha sonra grupların önerileri belli kriterlere göre ayrılan kategoriler temel alınarak içerik analizi ile incelenmiş ve tartışılmıştır. İçerik analizinde kategorisel analiz tekniği kullanılmıştır. Kategoriler "bilgi kaynaklarının yönetimi, bilgi okuryazarlığı becerileri ve kullanıcılara hizmet" olarak belirlenmiştir. Kategorilerin incelenmesinden sonra DEÜ Kütüphaneleri misyonu şekillenmiştir.

Bu grup çalışmalarında aynı zamanda üniversite kütüphanelerinin durum analizi (SWOT Analizi) gerçekleştirilmiştir. Böylece belirlenen misyona ulaş- 
mak için DEÜ Kütüphanelerinin güçlü ve zayıf yönlerini saptadıktan sonra çevredeki fırsat ve tehditler de dikkate alınarak geliştirilecek stratejiler belirlenmiştir.

Son olarak 16 kütüphane çalışanına bilgi okuryazarlığı uygulamalarının geliştirilmesinin başarılı olabilmesi için gerekli faktörleri algılamalarına yönelik bir anket uygulanmıştır. Bu ankette üniversite ve kütüphanenin misyonu, durum analizi dikkate alınarak kütüphanecilerin rolleri, bilgi okuryazarlığının önemi ve bunun DEÜ' de uygulanabilirliği belirlenmek istenmiştir. Anket detaylı bir literatür taraması sonucu çeşitli kaynaklardan yararlanılarak hazırlanmıştır. Ankete katılanlardan kütüphanecilerin rollerini içeren 16 ifadeyi 5'li önem ölçeğine göre değerlendirmeleri istenmiştir. Ölçekteki puanlama; 1=Hiç önemli değil, 2=Önemli değil, 3=Fikrim yok, 4=Önemli, 5=Çok önemli olarak belirtilmiştir. Ayrıca, ifadelerin içerdiği rollerin uygulanabilirliği 1=Kesinlikle uygulanamaz, 2=Uygulanamaz, 3=Fikrim yok, 4=Uygulanabilir, 5=Kesinlikle uygulanabilir ölçeği ile belirlenmeye çalışıımıştır.

Toplantının genel çerçevesi Tablo 2'de sunulmaktadır.

\begin{tabular}{|c|c|c|c|}
\hline Amaç & $\begin{array}{c}\text { Veri Toplama } \\
\text { Yöntemi }\end{array}$ & Analiz & Detaylar \\
\hline $\begin{array}{l}\text { DEÜ Kütüphanelerinin } \\
\text { misyonunun } \\
\text { belirlenmesi }\end{array}$ & $\begin{array}{l}\text { Dörder kişilik } \\
\text { grup çalışması }\end{array}$ & İçerik analizi & $\begin{array}{c}\text { Grup çalışmalarından } \\
\text { elde edilen } \\
\text { sonuçların } \\
\text { tartışılması }\end{array}$ \\
\hline $\begin{array}{l}\text { DEÜ Kütüphanelerinin } \\
\text { durum analizi }\end{array}$ & $\begin{array}{l}\text { Dörder kişilik } \\
\text { grup çalışması }\end{array}$ & Içerik analizi & $\begin{array}{c}\text { Grup çalışmalarından } \\
\text { elde edilen } \\
\text { sonuçların } \\
\text { tartışılması }\end{array}$ \\
\hline $\begin{array}{l}\text { Bilgi } \\
\text { okuryazarlığının } \\
\text { DEÜ'de } \\
\text { uygulanabilirliği }\end{array}$ & Anket & $\begin{array}{l}\text { Tanımlayıcı } \\
\text { istatistik }\end{array}$ & $\begin{array}{l}\text { Literatürdeki } \\
\text { çalışmalarda } \\
\text { belirlenen } 16 \\
\text { kütüphane } \\
\text { faaliyetinin test } \\
\text { edilmesi }\end{array}$ \\
\hline
\end{tabular}

Tablo 2: DEÜ Kütüphanesi ve Kütüphanecilerinin Konumlandırılması Toplantısının Genel Çerçevesi 


\section{Bulgular ve Değerlendirme}

Dokuz Eylül Üniversitesinin misyonu; "Atatürk ilke ve devrimleri çerçevesinde ezbercilikten uzak, yalnızca aklın ve bilimin geçerli olduğu, doğruları sorgulayarak, araştırarak ulaşmayı öğreterek uluslararası kalitede çağdaş eğitim vermek; her türlü düşünceye açık, aklın egemen olduğu özgür bir ortamda bilgiye ulaşılan, bilginin kullanıldığı, bilginin üretildiği, yaratıcı ve katılımcı bir üniversite ortamı yaratmak; sürekli öğrenmeyi öğrenen, soran, sorgulayan, araştıran, problem değil çözüm üreten, sosyal becerileri gelişmiş, kendine güvenen, doğru kararlar verebilen, akılcı, yaratıcı, üretken, insan haklarına saygılı, evrensel değerlere açık, topluma ve toplumsal sorunlara duyarlı, demokrat, aydın gençler yetiştirmek; üniversite-sanayi işbirliği ile bilgi ve teknoloji üreterek, toplumsal kalkınmaya katkıda bulunmak; ulusal ve evrensel değerlere sahip çıkarak toplumla bütünleşmek; eğitim, öğretim, araştırma ve uygulamada sürekli iyileşme ve gelişmeyi sağlamak; "önce insan" odaklı bir anlayışla mutlu bireylerden oluşan mutlu bir topluma ulaşmaktır" (Dokuz Eylül Üniversitesi, 2002, s. 7).

Grup çalışmaları sonucunda üniversitenin misyonu doğrultusunda DEÜ Kütüphaneleri misyonu ise şu şekilde geliştirilmiştir: Kullanıcıların eğitim, öğretim, araştırma ve toplumsal görevlerini yerine getirmeleri için gereksinim duydukları bilgi kaynaklarının yönetimini sağlamak; bilgi okuryazarlığı becerilerinin kazandırılmasında aktif görev üstlenmektir.

DEÜ Kütüphanelerinin durum analizi teknoloji etrafında şekillenmiştir. Teknolojik gelişmeler ve bunların üniversite yönetimi ve öğretim üyeleri tarafından kabulü kütüphaneyi olumlu yönde etkilerken; teknolojik gelişmelerin kütüphane faaliyetlerine uygulanmasında yaşanan gecikmelerin olumsuz etkileri görülmektedir. Basılı ve elektronik bilgi kaynaklarından oluşan güncel koleksiyonu, aktif kütüphane kullanıcısı olan genç öğretim elemanları, özverili personel, teknolojik gelişmelere uyum ve kabul, güçlü yönler olarak ifade edilirken; fiziksel koşulların ve teknik donanımın yetersizliği ve personel eksikliği, zayıf yönler olarak belirlenmiştir. Bilişim teknolojisindeki gelişmeler bir fırsat olarak görülürken; devlet, personel ve ücret politikası, ihale sistemi, ekonomik istikrarsızlık, kaynak maliyetlerinin artışı ve yetersiz mali kaynaklar tehdit olarak ele alınmaktadır. Uygulamanın son aşamasında yapılan anket çalışmasının sonuçları Tablo 3'de sunulmaktadır. 


\begin{tabular}{|c|c|c|}
\hline Bilgi Okuryazarlık Uygulamaları & $\begin{array}{l}\text { Uygulama } \\
\text { Önemi(*) }\end{array}$ & $\begin{array}{l}\text { DEÜ'de } \\
\text { Uygulanabilirliği }\left(^{* \star}\right)\end{array}$ \\
\hline $\begin{array}{l}\text { Kütüphaneciler, fakülteye yeni gelen akademik personele } \\
\text { bilgi kaynakları ve hizmetlerini tanıtmalıdır. }\end{array}$ & 4,86 & $\begin{array}{l}\text { Kesinlikle uygulanabilirliğine } \\
\text { katılıyorum }\end{array}$ \\
\hline $\begin{array}{l}\text { Kütüphaneciler, yeni gelen öğrencilere tanıtım } \\
\text { turu düzenlemeli ve kütüphane araştırma becerileriyle ilgili } \\
\text { eğitim vermelidir. }\end{array}$ & 4,86 & $\begin{array}{l}\text { Kesinlikle uygulanabilirliğine } \\
\text { katılıyorum }\end{array}$ \\
\hline $\begin{array}{l}\text { Kütüphaneciler, bilgi okuryazarlığı programlarının } \\
\text { etkin öğretmenleri olmalıdır. }\end{array}$ & 4,86 & $\begin{array}{l}\text { Kesinlikle uygulanabilirliğine } \\
\text { katılıyorum }\end{array}$ \\
\hline $\begin{array}{l}\text { Kütüphaneciler istenen kaynakları sağlamalı, bu kaynakların } \\
\text { kullanımını kolaylaştırmalıdır. }\end{array}$ & 4,71 & $\begin{array}{l}\text { Kesinlikle uygulanabilirliğine } \\
\text { katılıyorum }\end{array}$ \\
\hline $\begin{array}{l}\text { Kütüphaneciler, eğitim teknolojilerini öğrenme } \\
\text { faaliyetlerine uygulamalıdır. }\end{array}$ & 4,71 & $\begin{array}{l}\text { Kesinlikle uygulanabilirliğine } \\
\text { katılıyorum }\end{array}$ \\
\hline $\begin{array}{l}\text { Kütüphaneciler, bilgi okuryazarlığı programlarının } \\
\text { geliştirilmesinde yalnız öğretim elemanları ile değil, } \\
\text { bölümlerle de işbirliği yaparak verilen ödevlerde bilgi } \\
\text { okuryazarlığı prensiplerinin uygulanmasında etkin rol almalıdır. }\end{array}$ & 4,71 & $\begin{array}{l}\text { Kesinlikle uygulanabilirliğine } \\
\text { katılıyorum }\end{array}$ \\
\hline $\begin{array}{l}\text { Kütüphaneciler ve öğretim üyeleri arasında koleksiyon } \\
\text { geliștirme ile ilgili toplantılar yapılmalıdır. }\end{array}$ & 4,64 & $\begin{array}{l}\text { Kesinlikle uygulanabilirliğine } \\
\text { katılıyorum }\end{array}$ \\
\hline $\begin{array}{l}\text { Kütüphaneciler, farklı türlerde eğitim kaynakları oluşturmalıdır. } \\
\text { (Yazılı ve web-tabanlı kitapçıklar, kaynak kullanım rehberleri, } \\
\text { elektronik veri tabanları kullanımı için ipuçlaı). }\end{array}$ & 4,64 & $\begin{array}{l}\text { Kesinlikle uygulanabilirliğine } \\
\text { katılıyorum }\end{array}$ \\
\hline $\begin{array}{l}\text { Kütüphaneciler, değerlendirmelerden elde edilen verileri } \\
\text { yorumlayarak eğitim programlarının ve hizmetlerinin } \\
\text { geliștirmelisinde ve güncellenmesinde rol almalıdır. }\end{array}$ & 4,64 & $\begin{array}{l}\text { Kesinlikle uygulanabilirliğine } \\
\text { katılıyorum }\end{array}$ \\
\hline $\begin{array}{l}\text { Kütüphaneciler, kurumların ders programları geliştirme } \\
\text { sürecine dahil olmalı ve öğretim üyeleriyle kütüphane dışında } \\
\text { iletișim kurmalıdır. }\end{array}$ & 4,64 & $\begin{array}{l}\text { Kesinlikle uygulanabilirliğine } \\
\text { katılıyorum }\end{array}$ \\
\hline $\begin{array}{l}\text { Kütüphaneciler, kurumun eğitim ortamına uygun } \\
\text { eğitim metotları kullanmalıdır. }\end{array}$ & 4,57 & $\begin{array}{l}\text { Kesinlikle uygulanabilirliğine } \\
\text { katılıyorum }\end{array}$ \\
\hline $\begin{array}{l}\text { Kütüphaneciler farklı disiplinlerin bilgi yapısına } \\
\text { ilișkin fikir sahibi olmalıdır. }\end{array}$ & 4,5 & $\begin{array}{l}\text { Kesinlikle uygulanabilirliğine } \\
\text { katılıyorum }\end{array}$ \\
\hline $\begin{array}{l}\text { Kütüphaneciler, fakülte öğretim elemanlarının isteği üzerine } \\
\text { ödevlerle ilgili araştırma süreci hakkında eğitim vermelidir. }\end{array}$ & 4,43 & $\begin{array}{l}\text { Uygulanabilirliğine } \\
\text { katılıyorum }\end{array}$ \\
\hline $\begin{array}{l}\text { Kütüphaneciler, öğrencilerin (bire-bir, danışma } \\
\text { masasında veya randevuyla), bilgi okuryazarlığı becerilerini } \\
\text { geliştirmeye yardımcı olmalıdır. }\end{array}$ & 4,29 & $\begin{array}{l}\text { Uygulanabilirliğine } \\
\text { katılıyorum }\end{array}$ \\
\hline $\begin{array}{l}\text { Kütüphaneciler, tez hazırlayan öğrencilerin bilgi } \\
\text { gereksinimleriyle ilgili danışmanlık yapmalıdır. }\end{array}$ & 4,21 & $\begin{array}{l}\text { Uygulanabilirliğine } \\
\text { katılıyorum }\end{array}$ \\
\hline $\begin{array}{l}\text { Kütüphaneciler, geleneksel sınıflarda veya } \\
\text { laboratuvarlarda grup eğitimi vermelidir. }\end{array}$ & 4,07 & $\begin{array}{l}\text { Uygulanabilirliğine } \\
\text { katılıyorum }\end{array}$ \\
\hline
\end{tabular}

Tablo 3: Bilgi Okuryazarlığı Uygulamalarında Kütüphanenin Önemi ve Katkısının Belirlenmesi

*Ifadelerin Önemi 1=Hiç önemli değil, 2= Önemli değil, 3= Fikrim yok, 4= Önemli, 5= Çok önemli olarak belirtilmiştir.

**Ifadelerin içerdiği rollerin uygulanabilirliği 1= Kesinlikle uygulanamaz, 2= Uygulanamaz, 3= Fikrim Yok, 4= Uygulanabilir, 5= Kesinlikle uygulanabilir. 
Tablo 3'de literatürde bilgi okuryazarlığı uygulamalarının başarısı için gerekli olduğu belirtilen kütüphanecilerinin rolleri ve DEÜ'de uygulanabilirliğine yönelik yapılan ankete ilişkin bulgular yer almaktadır.

Genel olarak değerlendirildiğinde ankette belirtilen kütüphaneci rollerinin hepsinin önemli olarak algılandığı görülmektedir. Ortalamalar incelendiğinde yeni gelen akademik personele bilgi kaynakları ve hizmetlerinin tanıtımı, yeni gelen öğrencilere tanıtım turu düzenlenmesi ve kütüphane becerileriyle ilgili eğitim verilmesi, kütüphanecilerin bilgi okuryazarlığı programlarının etkin öğretmenleri olmalarını içeren ifadelerin en yüksek değeri taşıdığı anlaşımaktadır (Ort=4,86). Kütüphanecilerin geleneksel sınıflarda veya laboratuvarlarda grup eğitimi vermeleri ise diğerlerine göre daha düşük ortalama değere sahiptir.

Çalışmaya katılan kütüphaneciler söz konusu rollerin tümünün DEÜ'de uygulanabirliğine inandıklarını ifade etmektedirler.

\section{Sonuç ve Öneriler}

Günümüzde kurumların ve örgütlerin rekabet edebilmelerinde, en önemli girdinin insan gücü olduğu bir gerçektir. Ekonomik, politik ve özellikle teknolojik değişimler yüksek düzeyde farklı niteliklere sahip insan gücü gereksinimini artırmıştır. Bu gereksinimi karşılayabilmenin bir yolu da örgün eğitimin yanı sıra birey odaklı, sürekli kendini yetiştirmeye dönük yaşam boyu öğrenmedir.

Yaşam boyu öğrenme bilincinin yaratılmasında bilgi okuryazarı bireyler yetiştirmenin önemi yadsınamaz. Yapılan incelemeler özellikle gelişmiş ülkelerde birçok üniversitede, bilgi okuryazarlığı uygulamalarının geliştirildiğini göstermektedir. Bilgi okuryazarlığı uygulamaları, kurumdaki tüm kişileri (üniversite yönetimi, öğretim üyeleri, öğrenciler, kütüphaneciler) yakından ilgilendirdiğinden öncelikle bilgi okuryazarlığı kavramının anlaşılması ve öneminin vurgulanması gerekmektedir. Daha sonra uygulamanın tanıtımı yapılmalı, bu zaman sürecinde uygulama sırasında çıkan eksiklikler belirlenmeli, eksikliklerin giderilmesi için çeşitli önlemler alınmalı ve proje geliştirilerek eğitim verilmelidir.

Bilgi okuryazarı bireyler yetiştirmenin en önemli ögeleri kütüphaneler ve kütüphanecilerdir. Bibliyografik eğitimde zaten önemli bir yere sahip olan kütüphanecilerin, bilgi okuryazarlığı kavramı kapsamında görev ve sorumlulukları daha da artmıştır. 
Bu gerçeklerden hareketle, DEÜ'nde bilgi okuryazarlığı projesi hazırlanmış, öncelikle kütüphane ve kütüphanecilerin konumları incelenerek verilmesi gereken eğitim programları belirlenmiştir.

Projenin ilk aşamasında bilgi okuryazarlığı kavramı açıklanarak tanıtılmış ve önemi vurgulanmıştır. Bilgi okuryazarlığı kapsamında ve üniversitenin misyonu çerçevesinde kütüphanelerin yetki ve görevleri belirlenerek durum analizi yapılmıştır. Kütüphanelerin misyonunu gerçekleştirebilmesi için güçlü yanlarıyla çevredeki tehditlerle başa çıkabilmesi, elde edeceği fırsatlar ile de ne tür stratejiler geliştirmesi gerektiği tartışılmıştır.

Bu çerçevede kütüphaneciler görev ve sorumluluklarının bilincinde olduklarını ve üstlenmesi gereken rollerin önemini ifade etmişlerdir. Ayrıca grup çaIışmaları sırasında bilgi okuryazarlığı uygulamalarının önemini vurgulamışlar ancak uygulama için eğitim gereksinimleri olduğunu da dile getirmişlerdir.

Bilgi okuryazarlığı uygulamalarının geliştirilmesi aşamasında kütüphanecilerin eğitim gereksinimlerinin belirlenmesi önemli bir faktör olarak karşımıza çıkmaktadır. Kütüphanecilik eğitimi almış olan ile almamış kütüphane personeline verilecek eğitim programının içeriğinin farklı olacağı açıktır. Kütüphanecilik eğitimi almış ancak bilgi okuryazarlığı eğitimi verme konusunda yeterli olmadığını düşünen personele sınıf yönetimi, öğrenci bakış açısını anlayabilme, bilgi okuryazarlığı yetkinliklerini uygulama, eğitim materyali geliştirme, öğrencilerin öğrenme düzeylerini değerlendirme, liderlik ve mesleki işbirliğini geliştirebilme becerilerini kazandıracak programlar uygulanmalıdır.

Yukarda sayılanlara ek olarak, kütüphanecilik eğitimi almamış olan personele ise; temel kütüphanecilik bilgi, beceri ve sorumlulukları, bilgi okuryazarlığı ve bunun kütüphaneciliğe yansıması ve bilgi teknolojileri konularında eğitim programları geliştirilerek verilmelidir.

Öte yandan bilgi okuryazarı bireylerin yetiştirilmesinde üniversite kütüphanelerinin üzerlerine düşen görev ve sorumlulukları tam anlamıyla yerine getirebilmeleri için, üniversite ve araştırma kütüphanelerinde kütüphanecilik bölümü mezunu çalışanların olmasının önemini vurgulamakta yarar görmekteyiz. 


\section{Kaynakça}

ACRL (2002). National ACRL Institute for information literacy - best practices initiative. [Çevrim içi], Elektronik adres: http://www.earlham.edu/ libr/Plan.htm [3 Ekim 2002].

ACRL (2001). Objectives for information literacy instruction: A model statement for academic librarians. [Çevrim içi], Elektronik adres: http://www.ala.org/ACRL/Standards_and_Guidelines/Objectives_for_Inf ormation_Literacy_Instruction_A_Model_Statement_for_Academic_Li brarians.htm [4 Ekim 2002].

ACRL (2000). Information literacy competency standards for higher education. [Çevrim içi], Elektronik adres: http:// www.ala.org/ Content/NavigationMenu/ACRL/Standards_and_Guidelines/ Information_Literacy_Competency_Standards_for_Higher_Education.htm [23 Aralık 2001].

ACRL (1997). Guidelines for instruction programs in academic libraries. [Çevrim içi], Elektronik adres: http://www.ala.org/ Content/NavigationMenu/ACRL/Standards_and_Guidelines/Guidelines _for_Instruction_Programs_in_Academic_Libraries1.htm [4 Ekim 2002].

ALA (1998). A Progress report on information literacy: An update on the American Library Association presidential Committee on Information Literacy: Final report. [Çevrim içi], Elektronik adres: http://www.infolit.org/documents/progress.html [30 Ocak 2002].

ALA (1989). American Library Association Presidential Committee on Information Literacy. [Çevrim içi], Elektronik adres: http://www.ala.org/ Content/NavigationMenu/ACRL/Publications/White_Papers_and_Repor ts/Presidential_Committee_on_Information_Literacy.htm [30 Ocak 2002]

Angeley, R. ve Purdue J. Information literacy: An overview. [Çevrim içi], Elektronik adres: http://www.ac.wwu.edu/ dialogue/issue6.html [26 Aralık 2002].

Bilgin, N. (2000). İçerik analizi. Izmir: Ege Üniversitesi Edebiyat Fakültesi Yayınları.

California State University, Northridge. Library strategic plan. [Çevrim içi], Elektronik adres: http://library.csun.edu/susan.curzon/stratpln.html [11 Ekim 2002] 
Çakın, I. (2000). Üniversitelerimizin bilgiye erişim sorunları ile Ulusal Akademik Ağ ve Bilgi Merkezi. Bilgi Dünyası, 2000, 1(1): 26-41.

Çakın, I. (1998). Üniversitelerimizin bilgiye erişim ortamları: Genel değerlendirme. Hacettepe Üniversitesi Edebiyat Fakültesi Dergisi Cumhuriyetimizin 75. Yıl Özel Sayısı, s. 37-67.

Çapar, B. ve Gürdal, O. (2001). Kütüphanecilik Bölümü öğrencilerinin okuryazarlık durumu üzerine bir araştırma. Türk Kütüphaneciliği, 2001, 15(4): 407-418.

Çelik, A. (2000). Üniversite kütüphanelerinin geleceği. Bilgi Dünyası, 2000, 1(1): 42-55.

Doherty, J.J., Hansen, M.ary A. ve Kaya, K.K. (1999), Teaching information literacy skills in the information age: The need for critical thinking. Library Philosophy and Practice, 1(2), [Çevrim içi], Elektronik adres: http://www.uidaho.edu/ mbolin/doherty.htm [ 3 Ekim 2002].

Dokuz Eylül Üniversitesi. (2002). Kılavuz 2002. Izmir: DEÜ.

Doyle, C. (1994). Information literacy in an information society: A concept for the information age. ERIC Clearinghouse on Information and Technology. New York: Syracuse University.

Grassian, E. ve Kaplowitz, J.R. (2001). Information literacy instruction theory and practice. New York: Neal-Schuman Publishers.

Gürdal, O. (2000). Yaşamboyu öğrenme etkinliği "Enformasyon okuryazarlığı”. Türk Kütüphaneciliği, 14(2): 176-187.

Hacettepe Üniversitesi. Üniversitemiz: Tarihçe. [Çevrim içi], Elektronik adres: http://www.hacettepe.edu.tr/turkce/universitemiz/tarihce.shtml [11 Ekim 2002].

Hacettepe Üniversitesi Kütüphaneleri. (1999). Kütüphane hakkında. [Çevrim içi], Elektronik adres: http://www.library.hacettepe.edu.tr/ kutuphane.htm [11 Ekim 2002].

Kurbanoğlu, S. (2001). Öğrencilere bilgi okuryazarlığı becerilerinin kazandırımasının önemi ve okul kütüphanelerinin bu alandaki rolü. Bilgi Dünyası, 2(1):1-19. 
McCool, D. (1989). Staffing for bibliographic instruction issues and strategies for new and expanding programs. M.Patine and B.Katz (yay.haz), Integrating Library Use Skills into the General Eductaion Curriculum içinde (s. 17-24). London: Haworth Press.

Meulemans, Y, Y.N ve Brown, J. (2001). Educating instruction librarians: A model for library and information science education. Research Strategies, 18: 253-264.

Miller, D. ve Anderson, J.L. (1996). Developing an integrated library program. Ohio: Linworth Publishing.

Oberman, C. (2002). What the ACRL Institute for Information Literacy Best Practices Initiative tells us about the librarian as teacher, $68^{\text {th }}$ IFLA Council and General Conference: Libraries for Life: Democracy, Diversity, Delivery, August $18^{\text {th }}-24^{\text {th }}$ 2002, Glasgow, Scotland'da sunulan bildiri. [Çevrim içi], Elektronik adres: http://www.ifla.org/ IV/ifla68/papers/082-119e.pdf [10 Eylül 2002].

ODTÜ. (2002). ODTÜ hakkında. [Çevrim içi], Elektronik adres: http://www.odtu.edu.tr/about/geninfo.php [10 Şubat 2002].

ODTÜ. METU Library facts about online library. [Çevrim içi], Elektronik adres: http://swan.lib.metu.edu.tr/9.asp [11 Ekim 2002].

Rader, H. (1998). Faculty-librarian collaboration in building the curriculum for the millennium - the US experience. 64 $4^{\text {th }}$ IFLA General Conference, August $16^{\text {th }}-21^{\text {st }}$ 1998, Amsterdam, Holland'ta sunulan bildiri. [Çevrim içi], Elektronik adres: http://www.ifla.org/IV/ifla64/040-112e.htm [19 Ağustos 2002].

Rader, H. (1995). Information literacy and the undergraduate curriculum. Library Trends, 44(2): 270-279.

Rubin, R. (1998). Foundations of library and information science. London: Neal-Schuman Publishers.

Sprague, R. ve Watson, H.J. (1996). Decision support for management. New Jersey: Prentice Hall.

Tonta, Y. (2002). Bilgi erişim sorunları ve internet. A.Can, T.Gülle, O.Gürdal ve E.Yılmaz (yay.hazı.). 37. Kütüphane Haftası Bildirileri içinde (s. 52-62). Ankara: Türk Kütüphaneciler Derneği. 